E. V. S. Albuquerque, Embrapa Genetic Resources \& Biotechnology, PqEB Av.W5Norte 70770-917, Brasília, Brazil. E-mail: erika.albuquerque@embrapa.br

\title{
From basic to applied knowledge: larval development and sex morphology to control Leucoptera coffeella (Lepidoptera: Lyonetiidae)
}

I. O. $\operatorname{Motta}^{1,3}$ J. Dantas ${ }^{1,4}$, L. Vidal ${ }^{1,5}$, J. Bilio ${ }^{1,6}$, J. R. Pujol-Luz ${ }^{2,7^{*}}$, E. V. S. Albuquerque , $^{1, *}$

${ }^{1}$ Embrapa Genetic Resources \& Biotechnology, Brasília 70770-917, Brazil

${ }^{2}$ University of Brasilia, Zoology Department, Brasília, 70910-900, Brazil

${ }^{3}$ ORCID: 0000-0002-8777-2817

${ }^{4}$ ORCID: 0000-0002-2422-5808

${ }^{5}$ ORCID: 0000-0003-3259-3528

${ }^{6}$ ORCID: 0000-0002-9865-5851

${ }^{7}$ ORCID: 0000-0002-8621-4856

${ }^{8}$ ORCID: 0000-0003-3967-2384

*Both authors contributed equally to this work

\begin{abstract}
The coffee leaf miner Leucoptera coffeella (Guérin-Mèneville \& Perrottet), is a key pest in coffee producing countries. During their development, the larvae feed on the palisade parenchyma of the leaves forming mines. As a result, the photosynthetic area of the plant decreases, affecting coffee production. Despite the severity of the damage caused by coffee leaf miner (CLM), morphological aspects of the larval development and the adult genitalia remain unknown. It is important to identify more susceptible targets to an efficient and narrow control by natural or synthetic approaches, relies on determining the larval instars. Equally important is the sexing of the adult, in experiments aiming efficient ways to control CLM, as the study of pheromone-based control methods. This work presents the first morphological description of the four larval instars and the adult genitalia of $L$. coffeella. In each larval instar, we measured the Mean $\pm \mathrm{SD}(\mathrm{mm})$ of the cephalic capsules $\left(1^{\text {st }} 0,14 \pm 0,03 ; 2^{\text {nd }} 0,25 \pm 0,04 ; 3^{\text {rd }} 0,32 \pm 0,03 ; 4^{\text {th }} 0,42 \pm 0,03\right)$ and observed the following morphological details: primary setae, prolegs, crochets and ecdysial line of the cephalic capsule. In the adults, we observed the sexual structures present in both genitalia: male - bulbus ejaculatorius, valva, anellus, gnathos and aedeagus and female - ovipositor, sclerite and corpus bursae. The dissection of the adult specimens confirmed that the external morphology corresponds to the correct sex attribution in CLM adults. These results may support innovative and improved control strategies for CLM Integrated Pest Management (IPM).
\end{abstract}

Keywords: genitalia, damage, instar, insect pest, dimorphism 


\section{INTRODUCTION}

Annually, more than 160 million bags of coffee are consumed on all continents. Coffee is produced in the countries of the neotropical region in America, where the coffee leaf miner Leucoptera coffeella (Guérin-Méneville and Perrottet 1842) occurs (Mey 1994, Pereira et al. 2007). Even though Brazil is the world's largest coffee producer, the coffee leaf miner (CLM) is a key pest causing damages every year (Medina Filho et al. 1977, Vieira et al. 2006, Consórcio de Pesquisa do Café 2020). The CLM infestation impacts severely the coffee yield and bean quality (Gallo et al. 1988) in all Brazilian producing regions (Parra et al. 1981, Pantoja-Gomez et al. 2019) (Fig. 1).

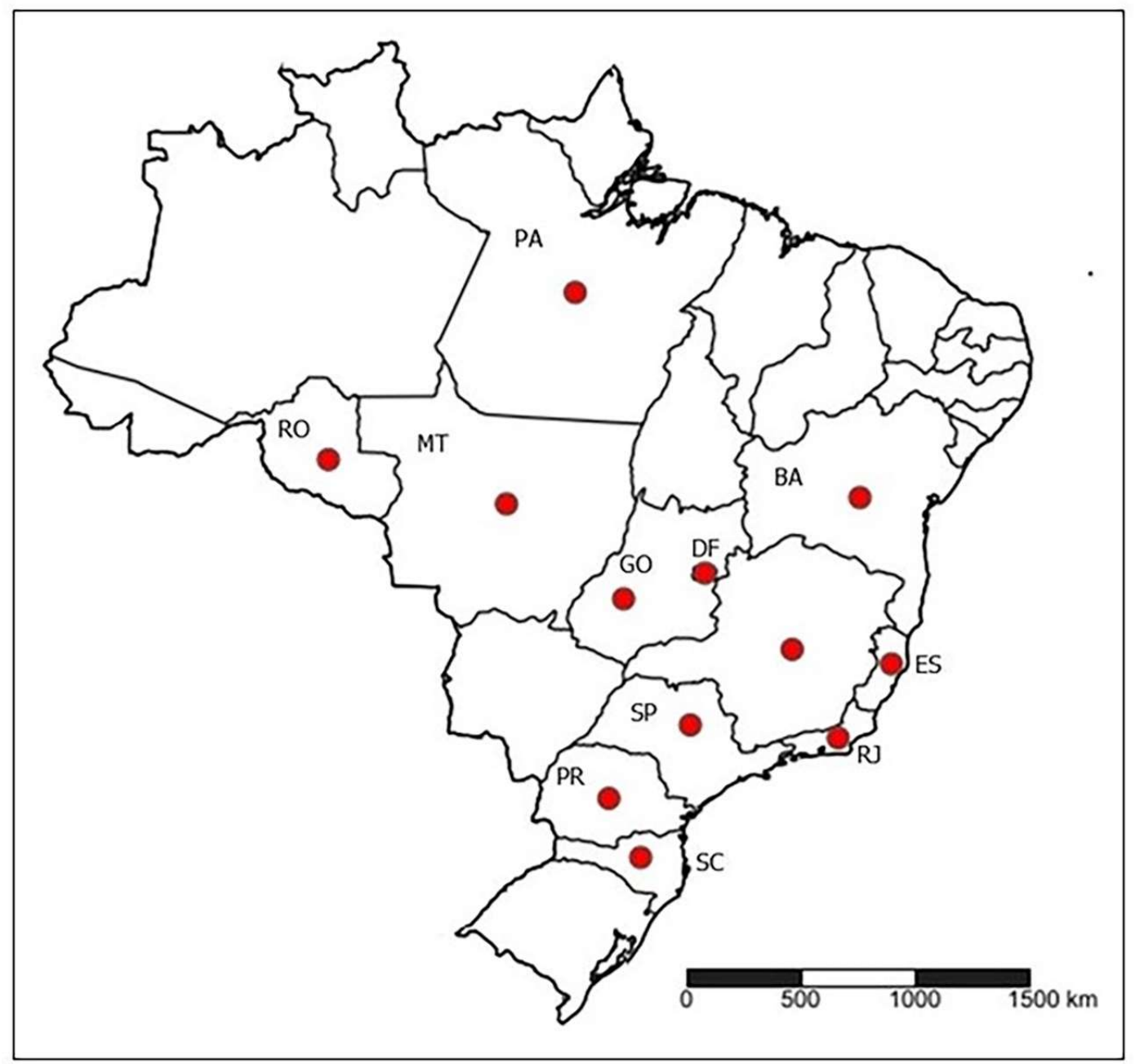

Fig. 1. States of Brazil with the incidence of Leucoptera coffeella. Rondônia (RO), Mato Grosso (MT), Pará (PA), Goiás (GO), Distrito Federal (DF), Bahia (BA), Minas Gerais (MG), Espírito Santo (ES), São Paulo (SP), Rio de Janeiro (RJ), Paraná (PR), Santa Catarina (SC).

The CLM is a monophagous pest (Reis and Souza 1986) which feeds exclusively on coffee leaves, seriously compromising the health of the plant. L. coffeella has been reported as responsible for losses that can reach up to $87 \%$ drop in productivity. Depending on the season, the defoliation of the coffee plant can reach up to $75 \%$ (Reis and Souza 1996, Neves 2006). 
The life cycle of $L$. coffeella is holometabolic, including the stages of egg, larva, pupa, and adult in its winged version (Box 1923) (Fig. 2). After being described by Guérin-Mèneville \& Perrottet in 1842, the immature forms (larva and pupa) were only described in 1923 by Harold Box. The larval phase penetrates the palisade parenchyma of the leaves and feeds there forming mines, which gives rise to the common name of this pest. The lesions caused by the mines cause necrosis, thus reducing the photosynthetic area, which can cause severe defoliation in more sensitive coffee genotypes, such as Coffea arabica (Medina Filho et al. 1977, Ramiro et al. 2004). The symptoms of this plague attack consist of mines that progress from light green to brown, as the larva develops and moves to new feeding sites (Fig. 3).
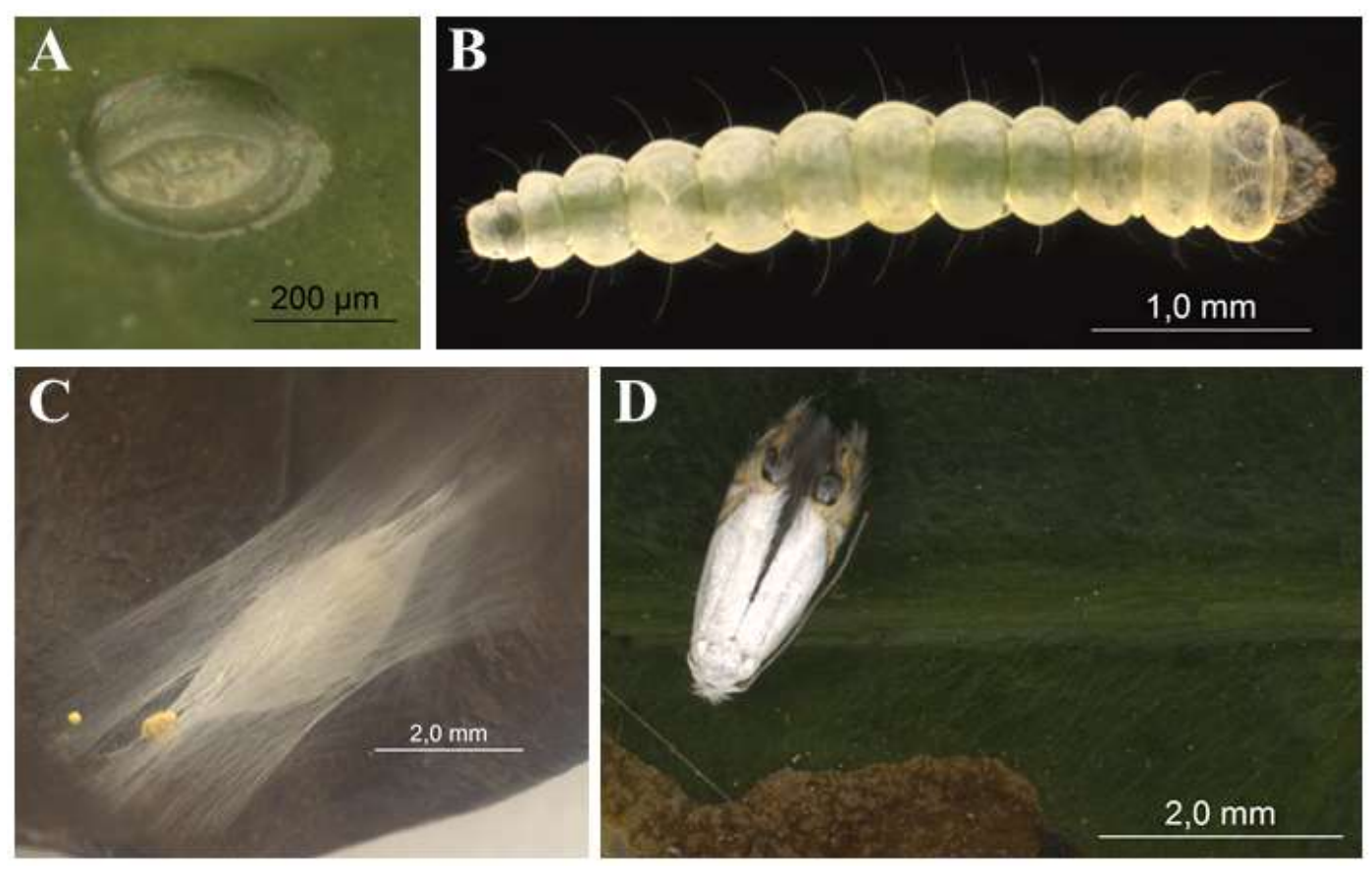

Fig. 2. Leucoptera coffeella life cycle phases. (A) Egg Stage. (B) Larval phase. (C) Pupa phase. (D) Adult.
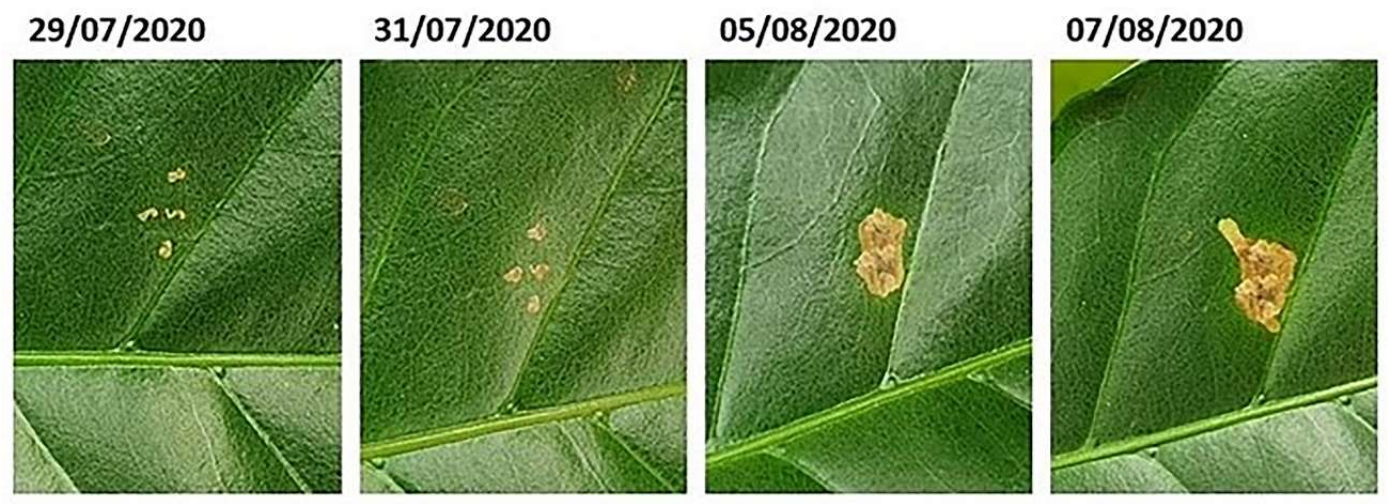

Fig. 3. Progression of mines formed by the coffee leaf miner Leucoptera coffeella, as the larva feeds on the palisade parenchyma of the leaf.

The knowledge of life cycle phases is critical to allow the development of pest control methodologies, e.g., oviposition assays, infestation challenge to test pesticide products or resistant cultivars. Studies aimed at chemical control, biological control, transcriptome, and plant resistance to Lepidoptera species pests are reported the use of 
specific larval instars. Whe larvae, Leucoptera meyricki, in the field with the application of insecticides sprayed on mined leaves in order to kill larvae of the $2^{\text {nd }}, 3^{\text {rd }}$ and $4^{\text {th }}$ instar, decreasing the development of the infestation. Fragoso et al. (2002) conducted a study, in the laboratory, with the use of organophosphate insecticides in larvae of the third instar of L. coffeella. Biological control agents of mining larvae have been studied by Draganonova an_ and Tomov (1998), in which the fungus species Beauveria bassiana, is a pathogen of last instar larvae of the species Leucoptera malifoliella. Camargo et al al._(2015) conducted a transcriptome study with the larval stages of the tomato leaf miner Tuta absoluta. Perthuis et 므._. (2005). tested the resistance of transformed C. canephora 126 using fourth instar larvae of CLM and Meriño_o_abrera et al. (2017) conducted a study with plant defense as an alternative to control CLM, using larvae of the fourth instar.

Adult sexing is used in experiments aimed at the mortality rate of females and males, laboratory breeding, sexual behavior, and pheromone employment. Informations about the male and female mortality rate of $L$. coffeella was observed by Notley (19 $\underline{4} \underline{4})$. Katiyar_and_Ferrer_(1968) conducted a study with CLM adult breeding techniques, presenting a cage model and suggesting feeding to keep specimens in laboratory conditions. The sexual behavior of CLM adults has been described in detail by Michereff. et al._(2007). Malo_et__al._(2009) conducted a study on the chemical composition of pheromones released by females of $L$. coffeella. Although the sexual dimorphism in adults of $L$. coffeella is mentioned in the literature (Parra 1985), there is no information available about the male and female genitalia of this species or the external aspects to differentiate them.

Despite the economic importance and geographical scope of the CLM, further studies on the larval morphological characteristics and sexual dimorphism of L. coffeella are lacking. In this work, we present a detailed study on the morphology of larvae for the identification of the four larval instars and description of male and female genitalia of $L$. coffeella.

\section{MATERIAL AND METHODS}

Insect Collection and Breeding: L. coffeella collections were carried out at Embrapa Cerrados (Federal District, Brazil, 15³6'15.1" S, 47 42'44.4" W) and Embrapa Genetic Resources \& Biotechnology (Federal District, Brazil, 1543'52.8 "S, 4754'10.2” W) between May and August 2020. Leaves with mines and pupae were collected directly from the coffee plant or leaves fallen on the ground around the plant. The leaves with larvae and pupae were taken to the laboratory where they were placed in breeding cages until adult emergence (Fig. 4). A sugary solution of water with industrialized sugar was offered ad libidum for adult feeding. 


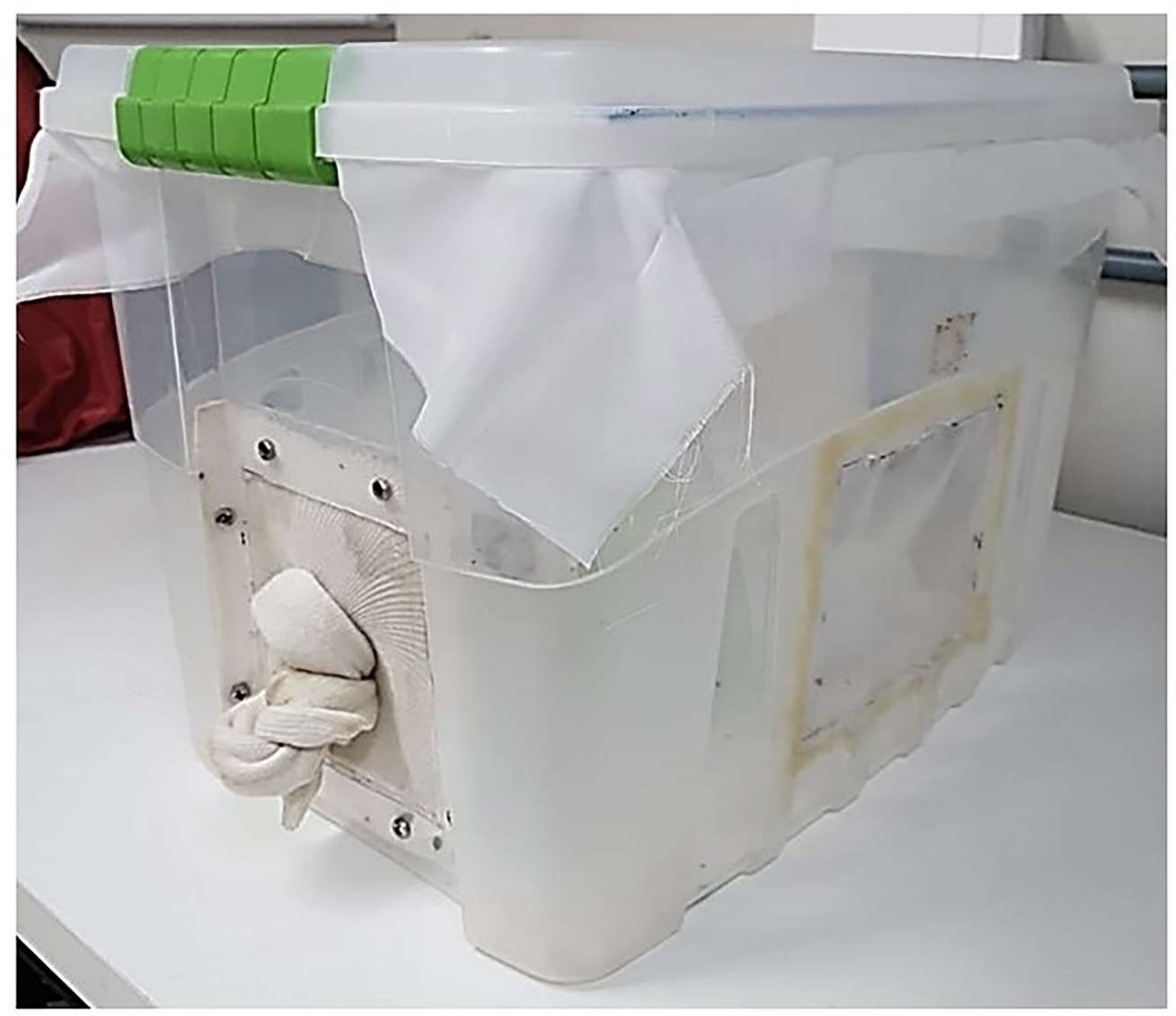

Fig. 4. Cage used in the creation of adults of Leucoptera coffeella in frontal-lateral view. At the front of the cage there is a fabric sleeve that assists in the internal handling of the cage, while on the side there is a voile net for air circulation.

Larvae: To examine the larvae and determine the number of instars, the infested leaf mines were opened using tweezers and scalpels and observed with a Leica EZ-4 (C) stereomicroscope. Cephalic capsule width and body length measurements were made using a Leica M205C (C) stereomicroscope and processed with the Leica LAS (C) V3.8 to morphometry and image acquisition software. The width of the cephalic capsule and the body length of 50 larvae were measured in each of the four larval instars. Larval morphological characteristics, associated with cephalic capsule measurements, follow Nielsen and Common (1991). To identify morphological characteristics to distinguish the larval stages, we used (1) presence of primary body setae in the first instar, (2) presence or absence of prolegs in the third instar (3) presence or absence of crochets in the fourth instar (4) presence or absence of ecdysial line in the frontal suture of the fourth instar. To observe these structures, the cephalic capsules were processed through diaphanization with $10 \% \mathrm{KOH}$ heated for about 2 minutes, and larvae were processed through diaphanization with $10 \% \mathrm{KOH}$ heated for about 6 minutes and then washed in water. The images were taken with a Leica DM-2000 (C) microscope coupled to a photographic camera and analyzed with Leica LAS (C) V3.8 software.

Genitalia: Male and female genitalia were processed through diaphanization of the abdomen with $10 \% \mathrm{KOH}$ heated, for about five minutes. Subsequently, they were washed in water and dissected in $70 \%$ alcohol. The photographs were taken with light microscopy 
(LM) using a Leica DFC295 camera mounted on a Leica M205C (C) stereomicroscope and Leica DM2000 (C) microscope. The specimens were measured ( $\mathrm{mm}$ ) with the Leica LAS (C) V3.8 software. The terminology of Nielsen and Common (1991) was used for the external morphology of the immature; Box (1923). for external adult morphology; Bradley and Carter (1982), Mey (1994) and Solis_and Metz_(2016) for male genitalia; Schmitt et al._(1996) and Matthews_and Miller_(2010) for female genitalia.

Map: The incidence map of the coffee leaf mining in Brazil was built using the SimpleMappr (C) program.

\section{RESULTS}

Morphological characteristics and chaetotaxy of the head and thorax were used to identify the four larval instars of $L$. coffeella. Also, we present a detailed study of the genitalia of males and females to better characterize both sexes.

Immature forms: 1st larval instar (Fig. 5A, B). Cephalic capsule variation 0,09-0,21 $\mathrm{mm}$ and body length variation $0,43-1,16 \mathrm{~mm}$. Body with translucent whitish coloration, pale yellow cephalic capsule with a defined chewing mouthpiece type (Fig. 5B), primary setae on the side of the body (Fig. 6A), and without prolegs. 2nd larval instar (Fig. 5C, D). Variation of the cephalic capsule $0,19-0,32 \mathrm{~mm}$ and variation in body length $0,71-$ $1,70 \mathrm{~mm}$. Body with pale yellow coloration, first body segment wider than the cephalic capsule, body setae longer than in the first instar and without prolegs. Mouthpiece with small spines (Fig. 6B). 3rd larval instar (Fig. 5E, F). Variation of the cephalic capsule $0,27-0,44 \mathrm{~mm}$ and variation in body length 1,39-2,38 $\mathrm{mm}$. Body and cephalic capsule with yellowish coloration, long body setae, presence of prolegs without defined crochets (Fig. 6C). 4th larval instar (Fig. 5G, H). Cephalic capsule variation 0,35-0,54 mm and body length variation $2,54-4,71 \mathrm{~mm}$. Yellowish body, prolegs with crochets in the shape of a uniordinal circle (Fig. 6D, E), and cephalic capsule with ecdysial line above the adfrontal suture (Fig. 6F). 

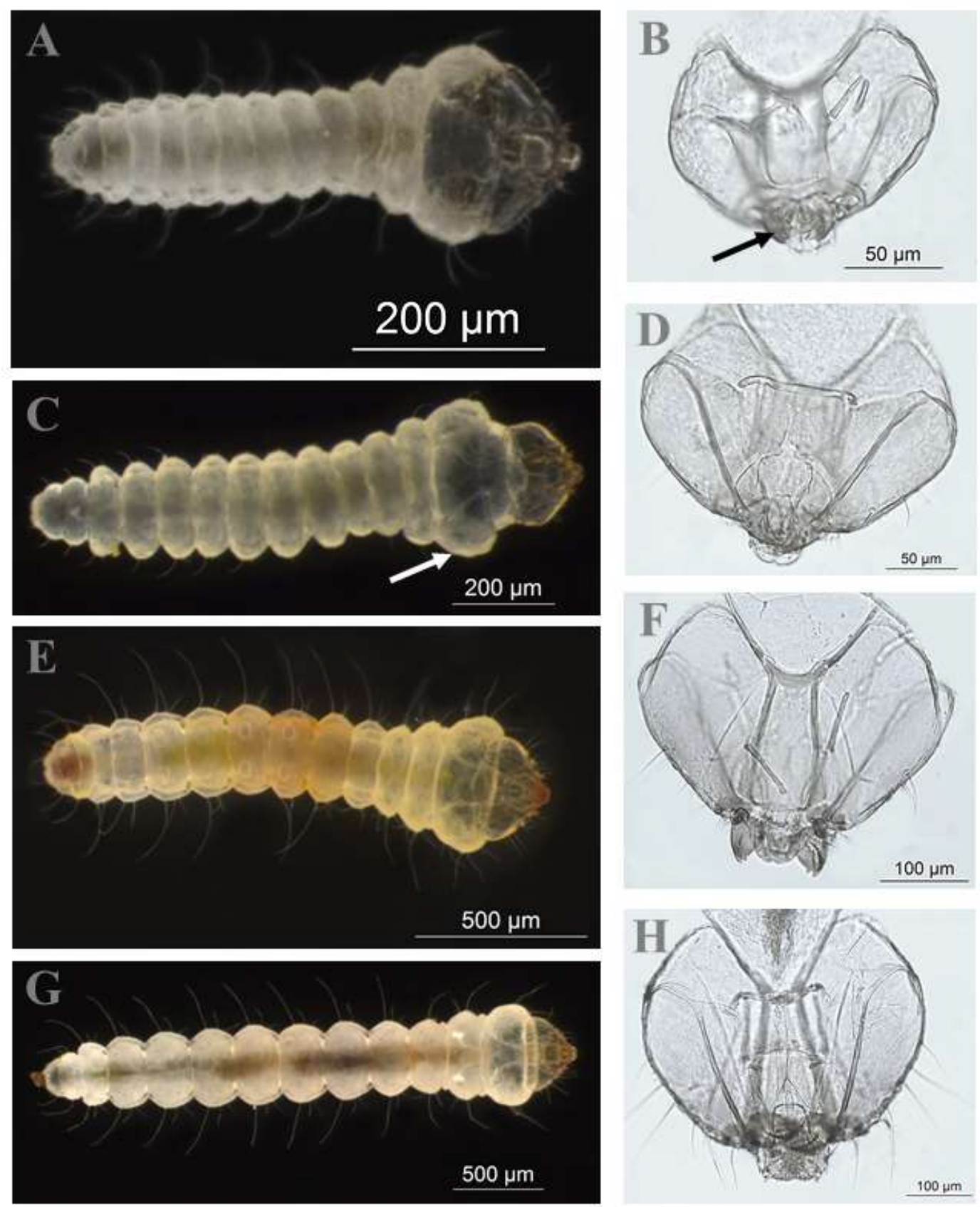

Fig. 5. Immatures of Leucoptera coffeella. (A) Larva of the first instar. (B) Cephalic capsule of the first larval instar. Arrow indicates chewing mouthpiece. (C) Larva of the second instar. Arrow indicates first body segment. (D) Cephalic capsule of the second larval instar. (E) Larva of the third instar. (F) Cephalic capsule of the third larval instar. $(\mathrm{G})$ Larva of the fourth instar. (H) Cephalic capsule of the fourth larval instar. 

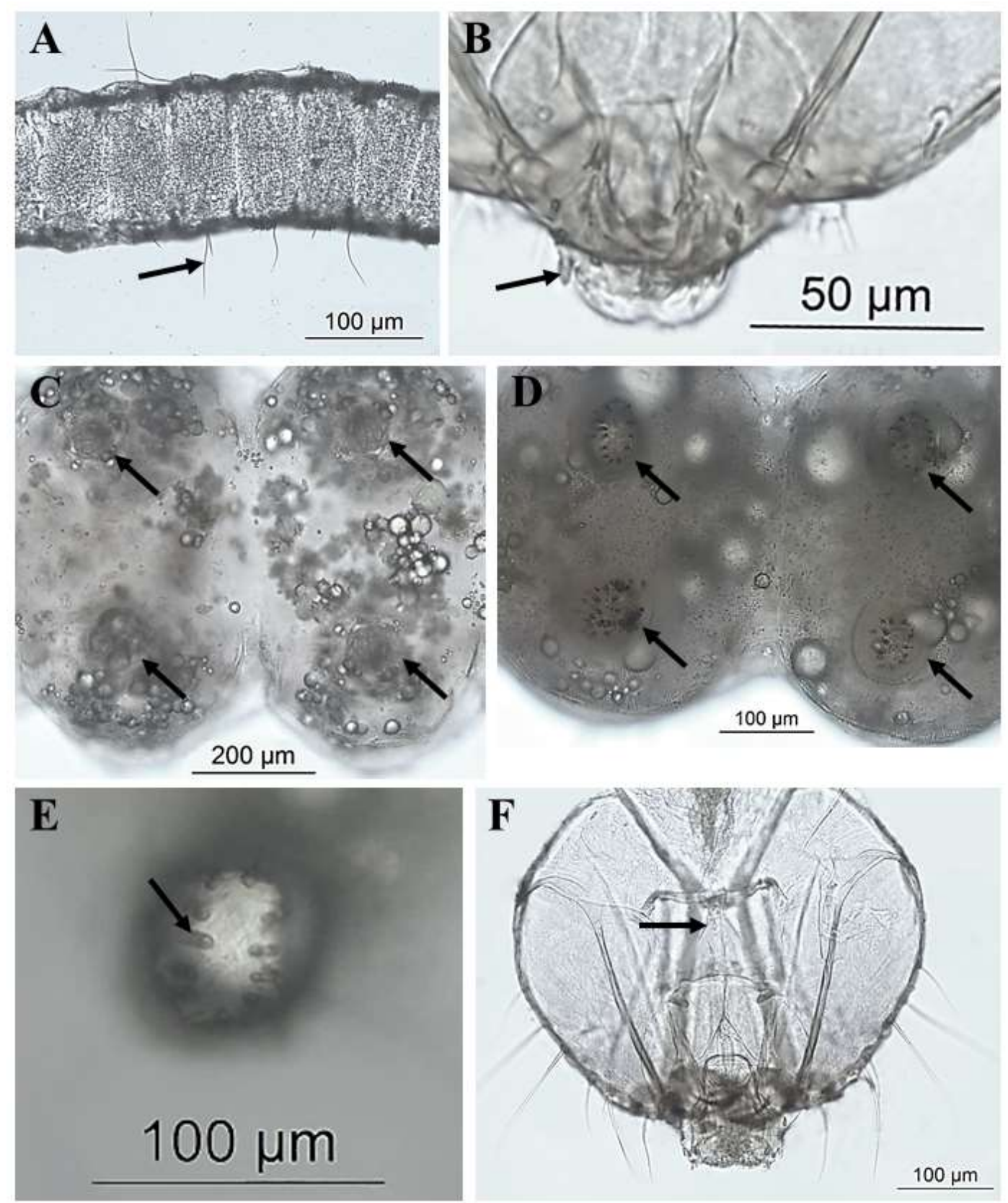

Fig. 6. External morphological characteristics of larvae of the coffee leaf miner Leucoptera coffeella. (A) Dorsal view of the larva body of the first larval instar. Arrow indicates primary seta. (B) Chewing mouthpiece of the second larval instar. Arrow indicates spine. (C) Ventral view of the third larval instar. Arrows indicate prolegs without crochets. (D) Ventral view of the fourth larval instar. Arrows indicate prolegs with crochets. (E) Ventral view of crochets in the shape of uniordinal circle in a fourth instar larva. Arrow indicates crochet. (F) Cephalic capsule of the fourth larval instar. Arrow indicates ecdysial line.

The morphometry of the immature forms $(\mathrm{N} 1 \mathrm{st}=50 ; \mathrm{N} 2 \mathrm{nd}=50 ; \mathrm{N} 3 \mathrm{rd}=50 ; \mathrm{N} 4$ th $=50$ ) was made based on the width of the cephalic capsule. The head grows in geometric progression and the width increases in a constant ratio, showing that there is variation in the size of the head in changing the larval instars as shown by Dyar_(18900), Bigger (1969), Ecole et al. (1999), Delbac et__al._(2010). The average cephalic capsule width and body length of the different instars are shown in Table 1. 
Table 1. Mean $( \pm \mathrm{SD})$ of variation in cephalic capsule measurements and body length in the 4 instars of Leucoptera coffeella.

\begin{tabular}{cccccc}
\hline Larval & \multirow{2}{*}{ no. } & \multicolumn{2}{c}{ Cephalic capsule width $(\mathbf{m m})$} & \multicolumn{2}{c}{ Body length $(\mathbf{m m})$} \\
\cline { 3 - 6 } Instar & & Range & Mean \pm SD & Range & Mean \pm SD \\
\hline $1^{\text {st }}$ & 50 & $0,09-0,21$ & $0,14 \pm 0,03$ & $0,43-1,16$ & $0,64 \pm 0,15$ \\
$2^{\text {nd }}$ & 50 & $0,19-0,32$ & $0,25 \pm 0,04$ & $0,71-1,70$ & $1,22 \pm 0,23$ \\
$3^{\text {rd }}$ & 50 & $0,27-0,44$ & $0,32 \pm 0,03$ & $1,39-2,83$ & $2,06 \pm 0,37$ \\
$4^{\text {th }}$ & 50 & $0,35-0,54$ & $0,42 \pm 0,03$ & $2,54-4,71$ & $3,60 \pm 0,63$ \\
\hline
\end{tabular}

Male Imago (Fig. 7A): External morphology. Average body length of 1,98 $\pm 0,03 \mathrm{~mm}$. Head. White scales on the dorsal apex. Base of the antenna white, with brownish length. Thorax. Covered with white scales. Legs. Long white scales. Wings. Long and thin, with two rounded black dots surrounded by yellowish scales. Apex of the wings with a row of black scales, laterally widened and with a "V" shape facing the posterior region of the body (Fig. 7C). Abdomen. White colored tergites. In ventral view, the last bipartite segment (Fig. 7B). Genitalia. Tergite 8 with coremata, forming a pair of elongated limbs with setae at the apex (Fig. 8A). Bilobate sternite 8, with an oval bulbus ejaculatorius (Fig. 8A). Bipartite valva, setose, and with small teeth in the internal region of the apex (Fig. 8B). Anellus fused medially and split at the apex, covering the valva (Fig. 8B). Gnathos elongated, forming a thin pair of arms (Fig. 8C). Short, cylindrical, and slender aedeagus at the apex (Fig. 8D).
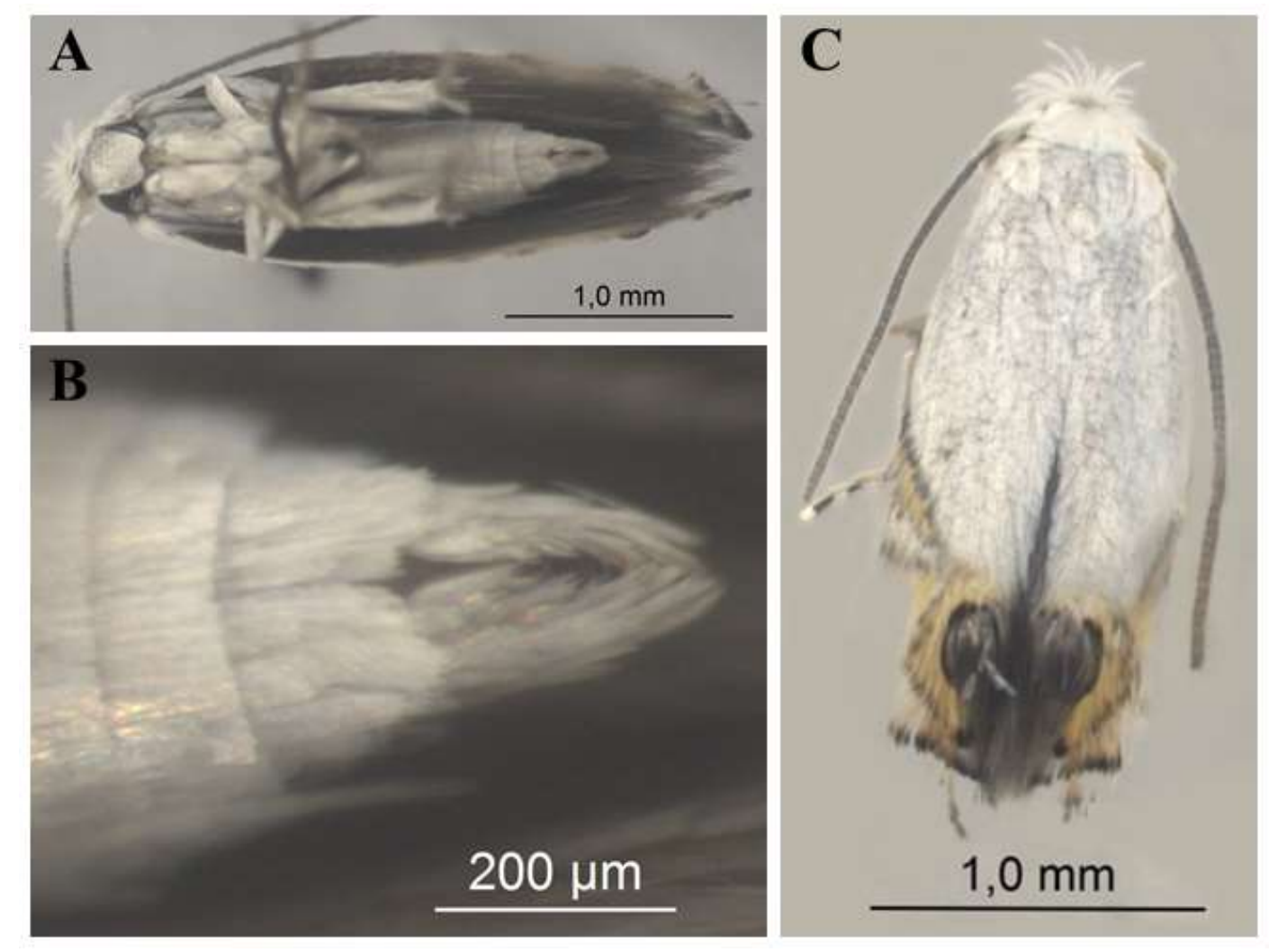

Fig. 7. Leucoptera coffeella, adult male. (A) Male ventral view. White-colored body scales. (B) Apex of male abdomen ventral view. (C) Male dorsal view. Apex of the wings with black dots surrounded by yellow scales, with a "V" shape facing the posterior region of the body. 

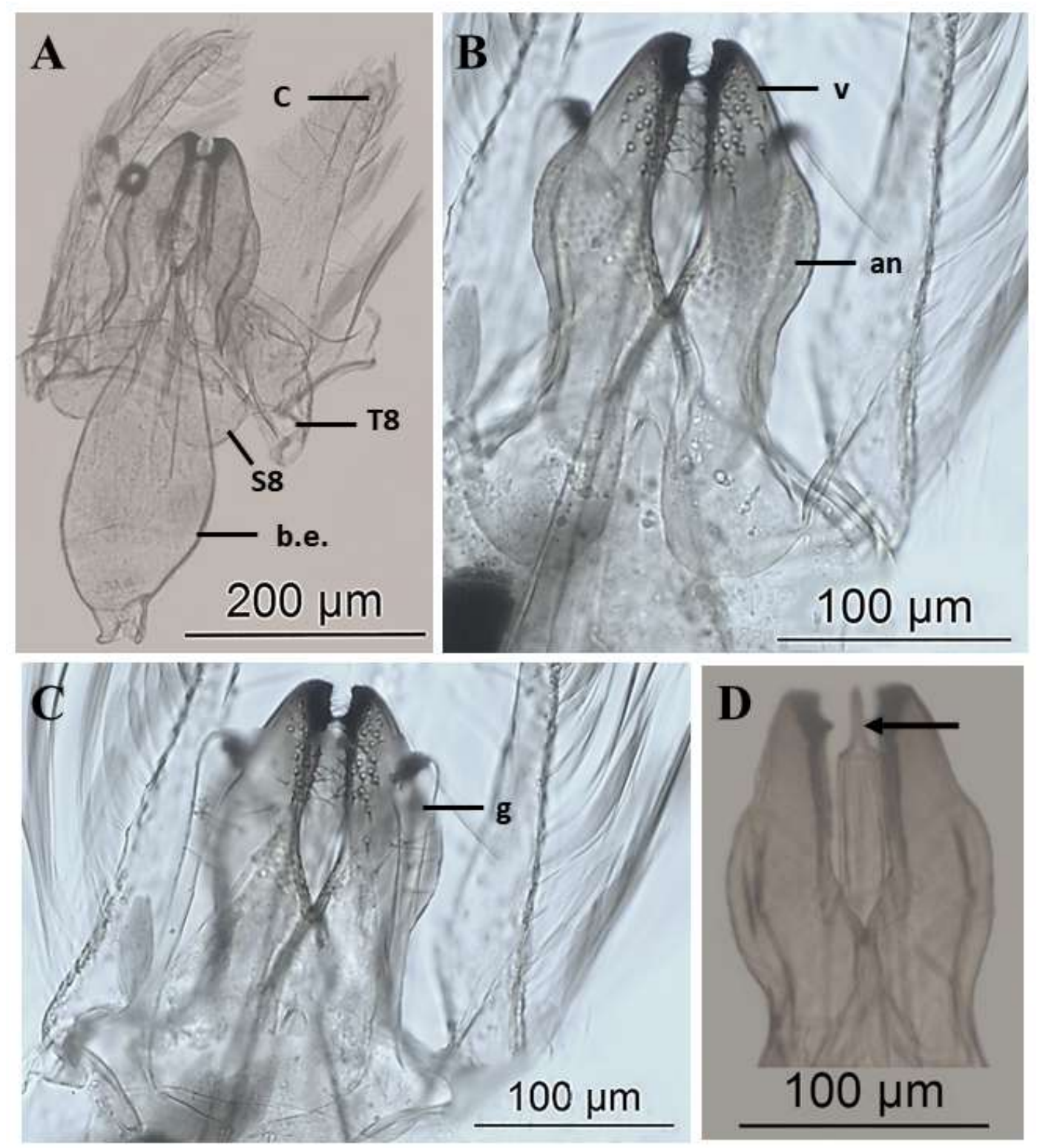

Fig. 8. Leucoptera coffeella, male genitalia. (A) Tergite 8, coremata, sternite 8 and ejaculatory bulb ventral view. (B) Valva and anellus ventral view. (C) Gnathos ventral view. d Aedeagus dorsal view. Arrow indicates apex of aedeagus. $\mathrm{C}=$ coremata, $\mathrm{T} 8=$ tergite $8, \mathrm{~S} 8=$ sternite 8 , b.e. $=$ bulbus ejaculatorius, $\mathrm{v}=$ valva, an = anellus, $\mathrm{g}=$ gnathos.

Female Imago (Fig. 9A): External morphology. Similar to the male except by: average body length of 2,11 $\pm 0,10 \mathrm{~mm}$. Apex of the wings narrower and with a " $\mathrm{C}$ " shape facing the anterior region of the body (Fig. 9C). In ventral view, the last segment with a tubular shape (Fig. 9B). Genitalia. Bilobed ovipositor with long apical setae (Fig. 10A). Scleritis of the ductus bursae apically tapered and enlarged in the anterior region; extremities of the anterior region are tapered and have a concave shape facing the apex (Fig. 10B). Oval membranous corpus bursae with small spines (Fig. 10C). 

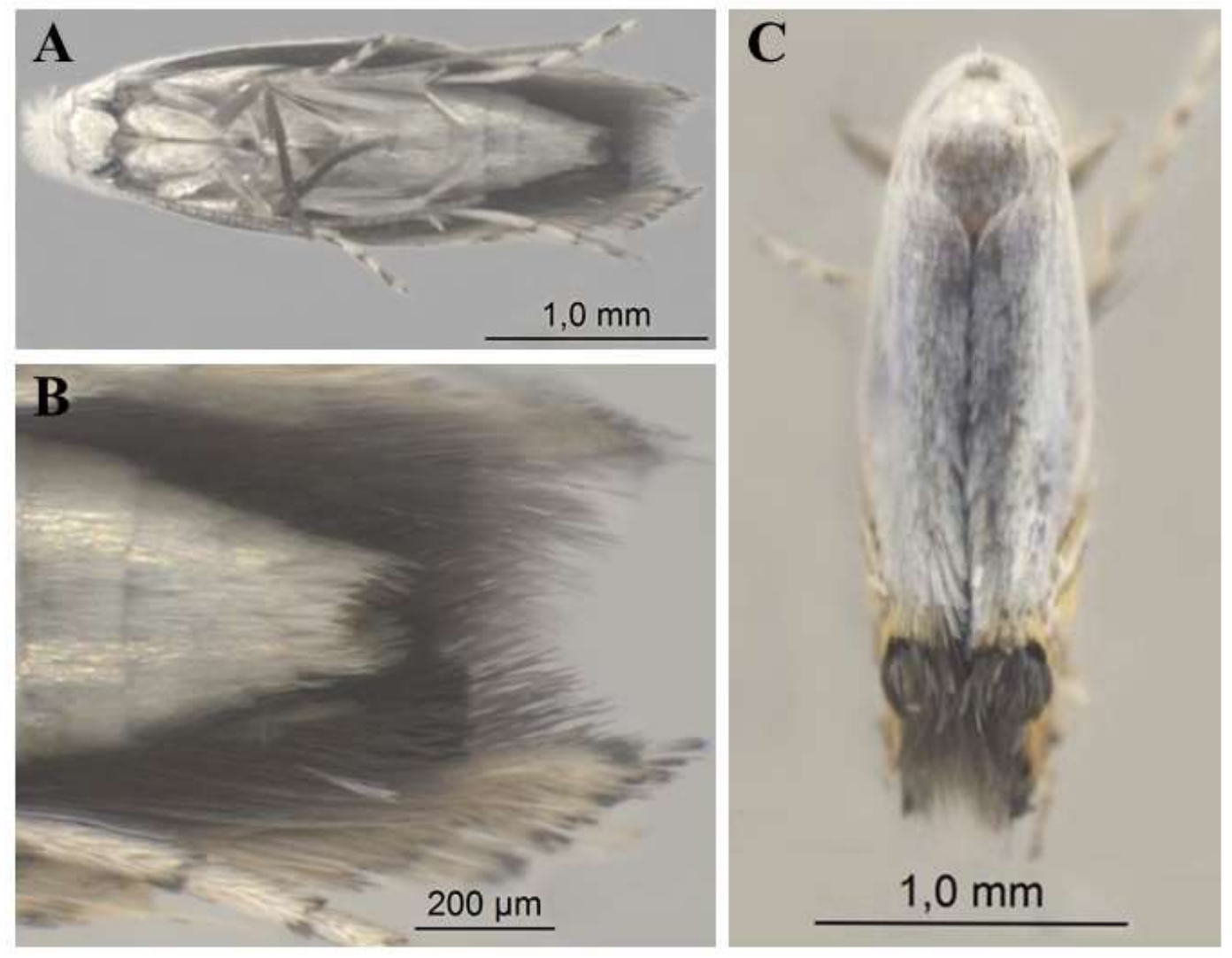

\section{$1,0 \mathrm{~mm}$}

Fig. 9. Leucoptera coffeella, adult female. (A) Female ventral view. (B) Apex of the female abdomen, ventral view. (C) Female dorsal view. Narrower body length when compared to males, apex of the abdomen with a "C" shape facing the anterior region of the body. 

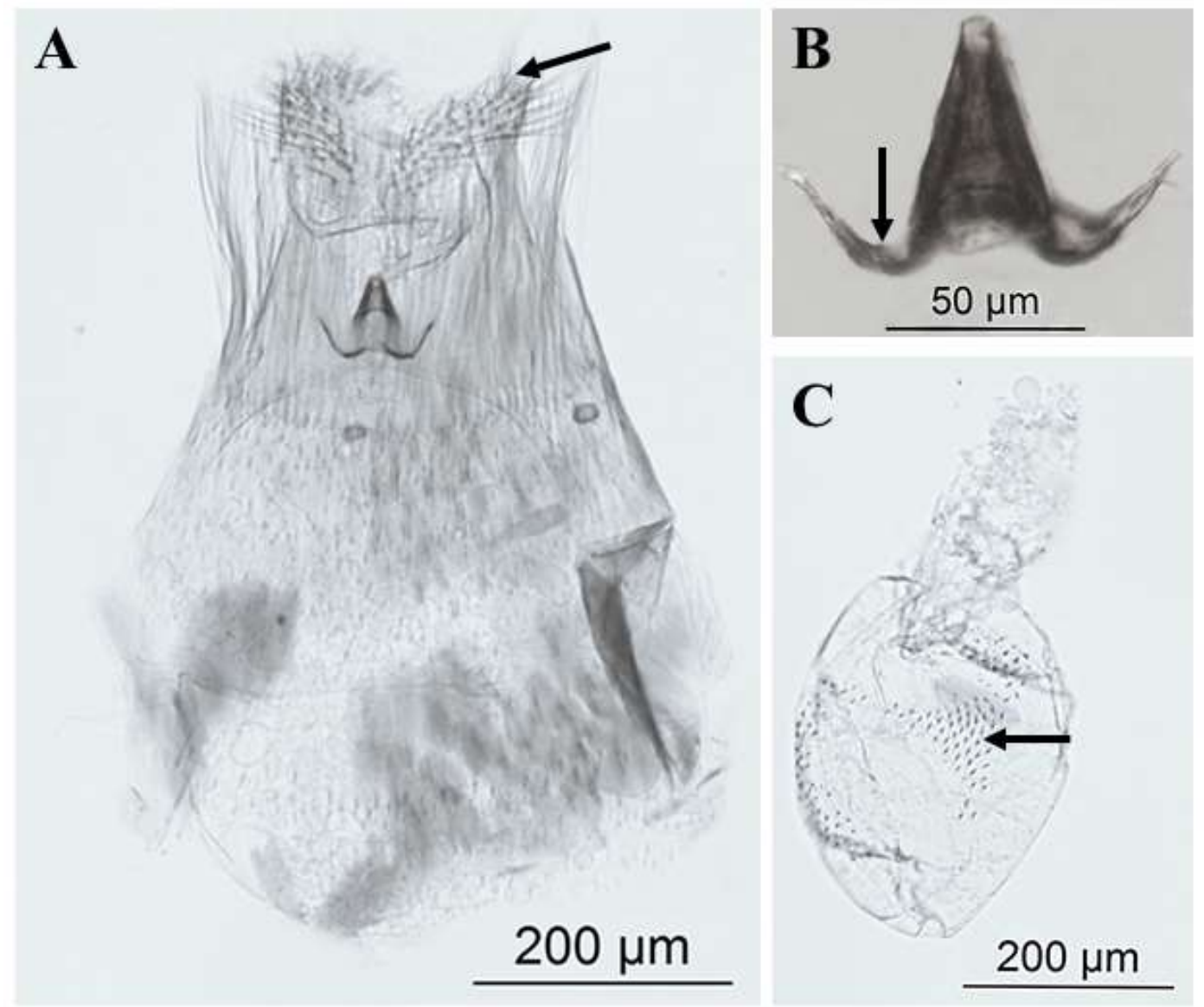

Fig. 10. Leucoptera coffeella, female genitalia. (A) Ovipositor ventral view. Arrow indicates ovipositor lobe. (B) Sclerite ventral view. Arrow indicates the sclerite's concave end. (C) Corpus bursae ventral view. Arrow indicates spines.

\section{DISCUSSION}

Leucoptera Hübner brings together leaf-mining moths that cause economic damage worldwide (Seven 2006, Magalhães et al. 2010). Despite the serious damage caused by L. coffeella to the coffee crop, knowledge gaps about the biology of the CLM remain to be fulfilled and made publicly available.

The CLM damage causing agents are all the larval stages before pupation (Notley 1948). Although Notley (1942 2 ) declared that L. coffeella has four larval instars, to our knowledge, there is no description of the morphological characteristics of each instar. The determination of Lepidoptera larval instars can be done by measuring the cephalic capsule (Dyar 1890, Ecole et al. 1999). After measuring the 200 larvae head capsule, the mean values were divided into four groups, one referring to each instar $\left(1^{\text {st }}\right.$ instar $0,14 \pm 0,03$ $\mathrm{mm}, 2^{\text {nd }}$ instar $0,25 \pm 0,04 \mathrm{~mm}, 3^{\text {rd }}$ instar $0,32 \pm 0,03 \mathrm{~mm}$ and $4^{\text {th }}$ instar $0,42 \pm 0,03 \mathrm{~mm}$ ), corroborating with Notley (1924) regarding the number of larval development stages. However, we have identified other morphological traits which can be useful to develop morphological markers of larval instars.

Besides length and width, the larval instars may also have different morphological characteristics (Nielsen and Common 1991). We observed that the $1^{\text {st }}$ larval instar of $L$. coffeella has primary arrows and no prolegs; $2^{\text {nd }}$ instar has arrows longer than $1^{\text {st }}$ instar and no prolegs; $3^{\text {rd }}$ instar presents prolegs without defined crochets and $4^{\text {th }}$ instar presents 
prolegs with defined crochets and ecdysial line. The larval instars of $L$. coffeella can be determined by the union of the head capsule measurements and the external body morphological characteristics.

To our understanding, the instar determination by the larval age is less precise than the morphological method we described here. In Navarro-_Gutiérrez_and GallardordoCovas (2009), a bioassay study that referred the larval instars according to their age, reported that, in laboratory at $27^{\circ} \mathrm{C}$, the $1^{\text {st }}$ instar correspond to 3 days, $2^{\text {nd }}$ to 7 days, $3^{\text {rd }}$ to 11 days and $4^{\text {th }}$ to 13 days. However, the CLM life cycle is shorter in dry climates combined with higher temperatures (Wolcott 1947, Dantas et al. 2020). Hence, it is highly probable that a natural variation is reflected in the life cycle timing due to the climatic conditions in the coffee crop (Costa et al. 2012).

In order to prevent economic losses the chemical control against CLM is widely used in areas of high incidence (Fragoso et al. 2001). One approach to CLM controlling is to refrain from oviposition, which often requires stronger chemicals to control adults. A huge drawback of using chemical pesticides is that this control can lead to pest resistance, as reported elsewhere (Leite et al. 2020). The selection and dispersion of insecticide resistance was correlated with a larger number of organophosphate applications and likely dispersion of resistant individuals on the CLM populations (Fragoso et al. 2003). Chemical control is also harmful to non-target organisms like wasps, long reported as natural CLM predators (Kay and Collins 1987, Pereira et al. 2007). Wasps are able to cut the coffee leaf epidermis prey on the CLM larvae (Fragoso et al. 2001, Tuelher et al. 2003).

Sexing CLM adults is important to conduct studies aiming the control of $L$. coffeella specimens in plantations using pheromones. The identification of males and females is essential to understand sexual behavior, sex-related mortality rates, and pheromone production (Notley 1948, Katiyar, K. P. \& Ferrer, F. 1968, Michereff et al. 2007, Malo et al. 2009). Semiochemicals can be used to alter the natural reproductive behavior of insects, decreasing pest population levels (Cardé and Minks 1995, Dantas et al. 2020). The CLM sexual pheromone was used to determine the pattern of pheromone production by females, as an indirect measure of the behavior calling for sexual intercourse (Lima et al. 2008). However, although several previous studies have used adult sexing, none has clearly explained how to differentiate males from females, so the methodology of sexing males and females has remained unclear.

The genitalia structures involved in the L. coffeella copulation are the male gnathos, for fixation with the female ovipositor, and the valva as both mechanical and sensory function. The aedeagus is inserted into the female to insemination, when the sperm, initially located in the bulbus ejaculatorius, is delivered in the female sclerite to reach the corpus bursae, causing the fertilization of the female (Powell and Opler 2009, Cordero and Baixeras 2015).

The elements in the male and female genitalia of $L$. coffeella corroborating the structures described for the other species of Lyonetiidae (Bradley and Carter 1982, Mey 1994) (Fig. 11). The L. coffeella male exhibits anellus, bulbus ejaculatorius, and aedeagus. These structures are common with the male genitalia of L. malifoliella. In $L$. coffeella, tergite 8 with setose coremata, bilobed sternite 8 , bipartite and setose valve, and elongated gnathos were observed, forming two thin arms. In contrast, pleurallobus, vinculum, pedunculus, subanalplatte, tuba analis are observed in L. malifoliella and this species does not have a valva (Mey 1994). In the female genitalia of L. coffeella, the 
structures we observed were bilobed ovipositor, sclerite in a conical shape, and oval corpus bursae with small spines. The corpus bursae was identified by Mey (1999) in the general structure of the Leucoptera female genitalia. The sclerite structure was identified by Schmitt et al._(1996) in another genus belonging to the Lyonetiidae family, where the female genital structure was characterized by a cruciform " $\mathrm{T}$ " shape, while in L. coffeella the sclerite has a conical shape (Fig. 12).

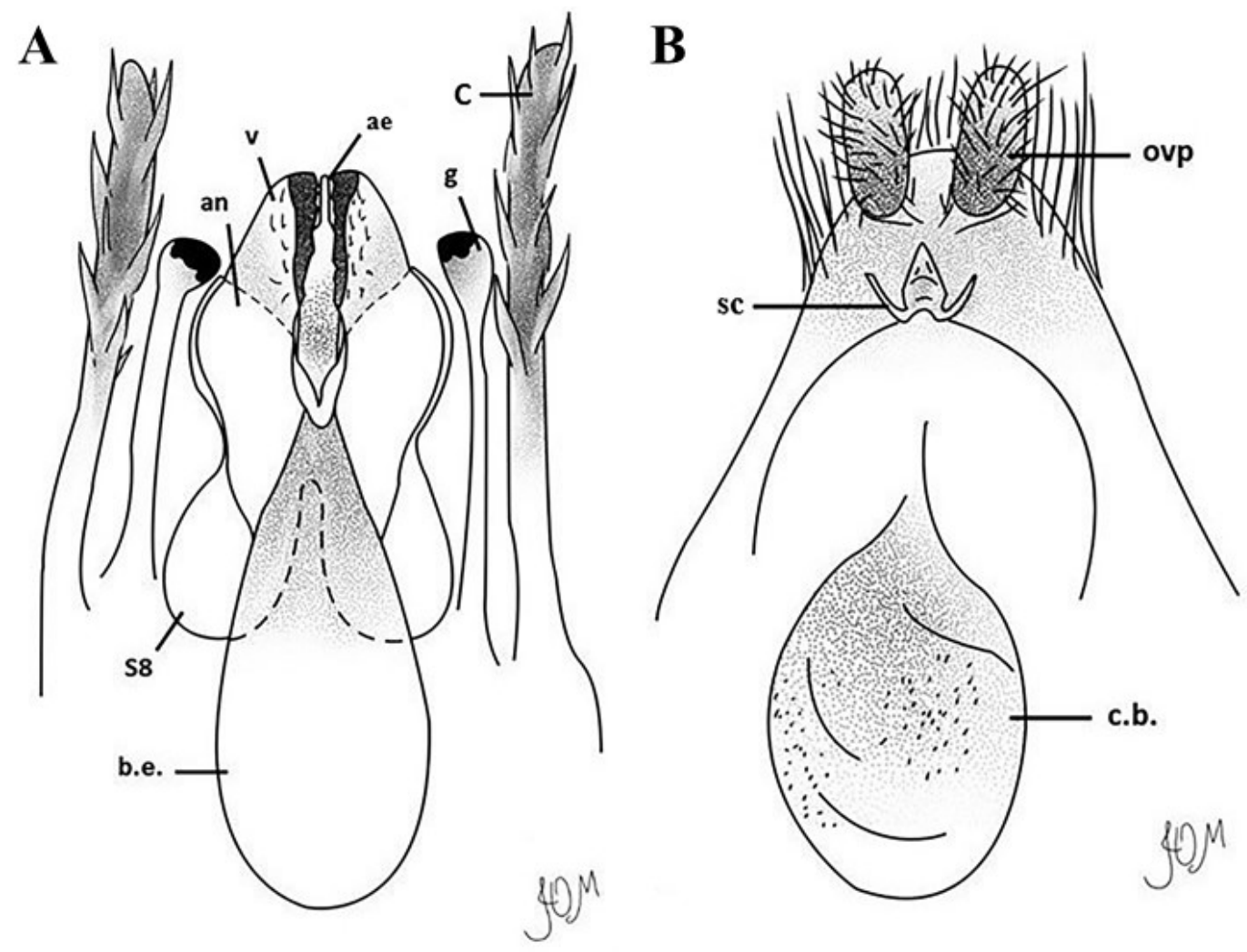

Fig. 11. Male and female genitalia of Leucoptera coffeella. (A) Genitalia of male dorsal view. (B) Genitalia of female ventral view. an $=$ anellus, b.e. $=$ bulbus ejaculatorius, c.b. $=$ corpus bursae, ae $=$ aedeagus, $s c=$ sclerite, $\mathrm{g}=$ gnathos, ovp $=$ ovipositor, $\mathrm{S} 8=$ sternite $8, \mathrm{C}=$ coremata, $\mathrm{v}=$ valva. 

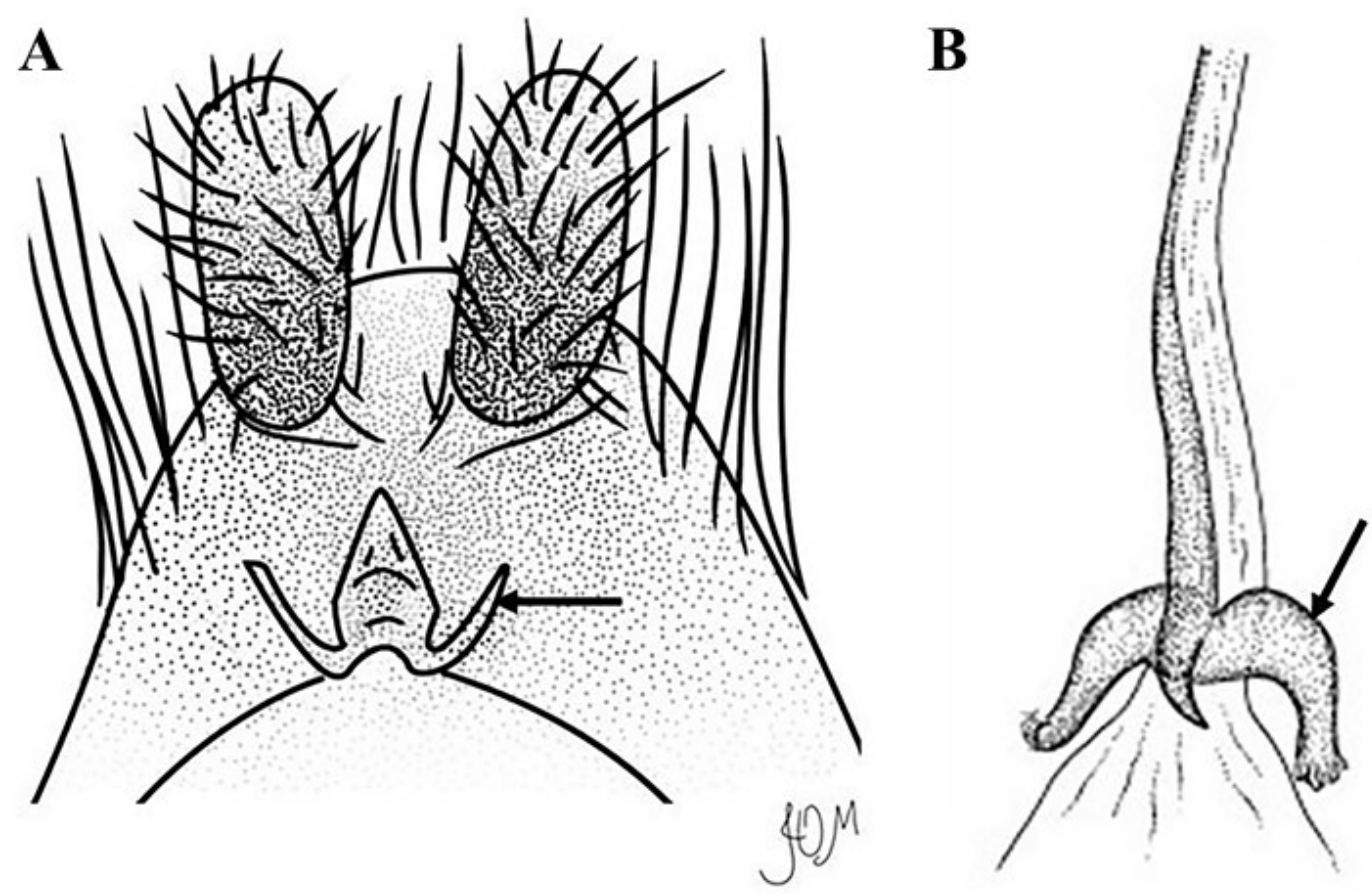

Fig. 12. Sclerite of species of the Lyonetiidae family. (A) Sclerite with conical shape of Leucoptera coffeella. Arrow indicates sclerite. (B) Lyonetia prunifoliella cruciform shaped sclerite (mod. S Schmitt $\underline{\text { et }} \underline{\text { al }} \underline{\mathrm{l}}$ 1996). Arrow indicates sclerite.

In conclusion, there are pest controls designed to be ovicidal, larvicidal, repellent or attractive to adult traps (Dantas et al. 2020). Different types of products can act at different stages of pest development and can be targeted to a specific sex. Thus, the identification of larval instars and adult sexes of $L$. coffeella are valuable to designing control strategies, as the discovery of new assets to bioproducts, nanoformulations, RNAi, and other strategies to improve sustainable IPM methods to control the CLM.

Acknowledgements: The authors are also thankful to Adriano Veiga from Embrapa Cerrados for providing access to coffee plantations and for helping with insect sampling. We thank Gabriela de Oliveira Motta for her assistance in the design of Leucoptera coffeella genitalia.The study was funded by Consórcio Brasileiro de Pesquisa e Desenvolvimento do Café - CBP\&D/Café grant number 10.18.20.004.00.00. The fellowships of Isabela de Oliveira Motta and João Bilio were funded by Fundação de Apoio à Pesquisa - FUNAPE and Leonardo Vidal by Embrapa.

Conflict of Interest: The authors declare that they have no conflict of interest.

\section{Author Contributions:}

- Author 1, author 2, author 3, author 4, author 5 and author 6 conceived research.

- Author 1, author 2, author 5 and author 6 conducted experiments.

- Author 2, author 5 and author 6 contributed material.

- Author 1, author 5 and author 6 analyzed data.

- Author 1, author 2, author 5 and author 6 wrote the manuscript.

- Author 6 secured funding.

All authors read and approved the manuscript. 


\section{REFERENCES}

Bigger, M. 1969. Partial Resistance of Arabica Coffee to The Coffee Leaf Miner Leucoptera Meyricki Ghesq. (Lepidoptera, Lyonetiidae). East African Agricultural and Forestry Journal. 34: 441-445.

Box, H. E. 1923. The Bionomics of the White Coffee-leaf Miner, Leucoptera coffeella, Guér., in Kenya Colony. (Lepidoptera, Lyonetidae.). Bull. Entomol. Res. 14: 133-145.

Bradley, J. D., and D. J. Carter. 1982. A new lyonetiid moth, a pest of winged-bean. System Entomol. 7: 1-9.

Camargo, R. de A., R. H. Herai, L. N. Santos, F. M. M. Bento, J. E. Lima, H. Marques-Souza, and A. Figueira. 2015. De novo transcriptome assembly and analysis to identify potential gene targets for RNAi-mediated control of the tomato leafminer (Tuta absoluta). BMC Genomics. 16: 635.

Cardé, R. T., and A. K. Minks. 1995. Control of Moth Pests by Mating Disruption: Successes and Constraints. Annu. Rev. Entomol. 40: 559-585.

(CPC) Consórcio de Pesquisa do Café. 2020. Exportações do café solúvel brasileiro atingem volume equivalente a 2,94 milhões de sacas de $60 \mathrm{~kg}$ em nove meses. (http://www.consorciopesquisacafe.com.br/index.php/imprensa/noticias/10182020-08-31-16-50-20) (accessed 21 October 2020).

Cordero, C., and J. Baixeras. 2015. Sexual Selection Within the Female Genitalia in Lepidoptera, pp. 325-350. In Peretti, A.V., Aisenberg, A. (eds.), Cryptic Female Choice in Arthropods: Patterns, Mechanisms and Prospects. Springer International Publishing, Cham.

Costa, J. N. M., C. A. D. Teixeira, J. R. V. Júnior, R. B. Rocha, and C. de F. Fernandes. 2012. Informações para facilitar a identificação das diferentes fases do bicho-mineiro (Leucoptera coffeella) em campo. Embrapa RondôniaComunicado Técnico INFOTECA-E, Rondônia.

Dantas, J., I. Motta, L. Vidal, J. Bílio, J. M. Pupe, A. Veiga, C. H. S. Carvalho, R. B. Lopes, T. L. Rocha, L. P. Silva, J. R. Pujol-Luz, and É. V. S. Albuquerque. 2020. A Comprehensive Review of the Coffee Leaf Miner Leucoptera Coffeella (Lepidoptera: Lyonetiidae), With Special Regard to Neotropical Impacts, Pest Management and Control. Preprints 2020, 2020100629.

Delbac, L., P. Lecharpentier, and D. Thiery. 2010. Larval instars determination for the European Grapevine Moth (Lepidoptera: Tortricidae) based on the frequency distribution of head-capsule widths. Crop Prot. 29: 623-630.

Draganova, S. A., and R. I. Tomov. 1998. Virulence of a strain Beauveria bassiana (Bals.) Vuill. (Hyphomycetes, Deuteromycotina) against larvae of Leucoptera malifoliella Costa (Lepidoptera, Lyonetiidae). Bulg J Agric Sci. 4: 435-439.

Dyar, H. G. 1890. The Number of Molts of Lepidopterous Larvae. Psyche: A Journal of Entomology. 5: 420-422.

Ecole, C. C., N. dos Anjos, M. M. Filho, and M. C. Picanço. 1999. Determinação do número de ínstares larvais em Plutella xylostella (L.) (Lepidoptera: Yponomeutidae). Acta Sci. Biol Sci. 21: 331-335.

Fragoso, D. B., R. N. C. Guedes, and J. A. Ladeira. 2003. Seleção na evolução de resistência a organofosforados em Leucoptera coffeella (Guérin-Mèneville) (Lepidoptera: Lyonetiidae). Neotrop. Entomol. 32: 329-334.

Fragoso, D. B., P. Jusselino Filho, A. Pallini Filho, and C. A. Badji. 2002. Acão de Inseticidas Organofosforados Utilizados no Controle de Leucoptera coffeella (Guérin-Mèneville) (Lepidoptera: Lyonetiidae) Sobre o Ácaro Predador 
Iphiseiodes zuluagai Denmark \& Muma (Acari: Phytoseiidae). Neotrop. Entomol. 31: 463-467.

Fragoso, D. B., P. Jusselino-Filho, R. N. C. Guedes, and R. Proque. 2001. Seletividade de inseticidas a vespas predadoras de Leucoptera coffeella (Guér.Mènev.) (Lepidoptera: Lyonetiidae). Neotrop. Entomol. 30: 139-143.

Gallo, D., O. Nakano, S. Silveira Neto, R. P. L. Carvalho, G. C. Batista, E. Berti Filho, J. R. P. Parra, R. A. Zucchi, S. B. Alves, and J. D. Vendramim. 1988. Manual de Entomologia Agrícola. Agronômica Ceres.

Guérin-Méneville, F., and S. Perrottet. 1842. Mémoire sur um insect et um champignon qui ravagent les cafiers aux Antilles. Mme. Ve. Bouchard-Huzard, Imprimeur-Libraire.

Katiyar, K. P. \& Ferrer, F. 1968. Rearing technique, biology and sterilization of the coffee leaf miner, Leucoptera coffeella Guer. (Lepidoptera: Lyonetiidae). International Atomic Energy Agency. 165-175.

Kay, I. R., and P. J. Collins. 1987. The Problem of Resistance to Insecticides in Tropical insect Pests. Int J Trop Insect Sci. 8: 715-721.

Leite, S. A., M. P. Dos Santos, G. A. Resende-Silva, D. R. da Costa, A. A. Moreira, O. L. Lemos, R. N. C. Guedes, and M. A. Castellani. 2020. Area-Wide Survey of Chlorantraniliprole Resistance and Control Failure Likelihood of the Neotropical Coffee Leaf Miner Leucoptera coffeella (Lepidoptera: Lyonetiidae). J Econ Entomol. 113: 1399-1410.

Lima, E. R., E. F. Vilela, T. M. C. Della Lucia, and L. M. S. Ataíde. 2008. Age and time related pheromone production in coffee leafminer Leucoptera coffeella Guérin-Méneville (Lepidoptera: Lyonetiidae). Journal of the Brazilian Chemical Society. 19: 1659-1662.

Magalhães, S. T. V., F. L. Fernandes, A. J. Demuner, M. C. Picanço, and R. N. C. Guedes. 2010. Leaf alkaloids, phenolics, and coffee resistance to the leaf miner Leucoptera coffeella (Lepidoptera: Lyonetiidae). J econ entomol. 103: 14381443.

Malo, E. A., J. C. Rojas, G. Lopez-Guillen, and J. F. Barrera. 2009. Chemical Analysis of Female Volatiles and Field Response of the Coffee Leafminer Moth (Lepidoptera: Lyonetiidae) to Stereoisomers of Its Major Sex Pheromone Component. flen. 92: 548-553.

Matthews, D. L., and J. Y. Miller. 2010. Notes on the Cacao Plume Moth in Honduras and description of the larvae and pupae (Lepidoptera: Pterophoridae). Trop Lepid. 20: 28-34.

Medina Filho, H. P., A. Carvalho, and L. C. Mônaco. 1977. Melhoramento do cafeeiro: XXXVII - Observações sobre a resistência do cafeeiro ao bichomineiro. Bragantia. 36: 131-137.

Meriño-Cabrera, Y., J. C. Zanuncio, R. S. da Silva, M. Solis-Vargas, G. Cordeiro, F. R. Rainha, W. G. Campos, M. C. Picanço, and M. G. de A. Oliveira. 2018. Biochemical response between insects and plants: an investigation of enzyme activity in the digestive system of Leucoptera coffeella (Lepidoptera: Lyonetiidae) and leaves of Coffea arabica (Rubiaceae) after herbivory. Ann Appl Biol. 172: 236-243.

Mey, W. 1994. Taxonomische Bearbeitung der westpaläarktischen Arten der Gattung Leucoptera Hübner, '1825', s. 1. (Lepidoptera, Lyonetiidae) 'Taxonomic revision of the westpalaearctic species of the genus Leucoptera Hübner, "1825", s. I. (Lepidoptera, Lyonetiidae).’ Dtsche Entomol Z. 41: 173-234. 
Michereff, M. F. F., M. Michereff Filho, and E. F. Vilela. 2007. Comportamento de acasalamento do bicho-mineiro-do-cafeeiro, Leucoptera coffeella (GuérinMèneville) (Lepidoptera: Lyonetiidae). Neotrop. entomol. 36: 376-382.

Navarro-Gutiérrez, P., and F. Gallardo-Covas. 2009. Host Instar Preference of Mirax Insularis (Muesebeck) (Hymenoptera: Braconidae), a Koinobiont Parasitoid of Leucoptera Coffeella Guerin-Meneville (Lepidoptera: Lyonetiidae). J Agric Univ PR. 93: 139-142.

Neves, D. M. F. 2006. Análise dos Benefícios Econômicos e Sociais da Utilização do Carbofurano no controle de Nematoides, Bicho Mineiro (Leucoptera coffeella) e Cigarra do Cafeeiro (Quesada gigas e Fidicina pronoe) na Cultura do Café. 29.

Nielsen, E., and I. Common. 1991. The Insects of Australia: A Textbook for Students and Research Workers. Melbourne University Press.

Notley, F. B. 1948. The Leucoptera leaf miners of coffee on Kilimanjaro. 1.Leucoptera coffeella, Guér. Bull. Entomol. Res. 39: 399-416.

Pantoja-Gomez, L. M., A. S. Corrêa, L. O. de Oliveira, and R. N. C. Guedes. 2019. Common Origin of Brazilian and Colombian Populations of the Neotropical Coffee Leaf Miner, Leucoptera coffeella (Lepidoptera: Lyonetiidae). J Econ Entomol. 112: 924-931.

Parra, J. 1985. Biologia comparada de Perileucoptera coffeella (Guérin-Mèneville, 1842) (Lepidoptera, Lyonetiidae) visando ao seu zoneamento ecológico no Estado de São Paulo. Rev Bras Entomol. 29: 45-76.

Parra, J., W. Gonçalves, and A. Precetti. 1981. Flutuação populacional de parasitos e predadores de Perileucoptera coffeella (Guérin-Méneville, 1842) em três localidades do estado de São Paulo. Turrialba. 31: 357-364.

Pereira, E. J. G., M. C. Picanço, L. Bacci, T. M. C. D. Lucia, É. M. Silva, and F. L. Fernandes. 2007. Natural mortality factors of Leucoptera coffeella (Lepidoptera: Lyonetiidae) on Coffea arabica. Biocontrol Sci Tech. 17: 441455.

Perthuis, B., J. L. Pradon, C. Montagnon, M. Dufour, and T. Leroy. 2005. Stable resistance against the leaf miner Leucoptera coffeella expressed by genetically transformed Coffea canephora in a pluriannual field experiment in French Guiana. Euphytica. 144: 321-329.

Powell, J., and P. Opler. 2009. Moths of Western North America. Berkeley: University of California Press.

Ramiro, D. A., O. Guerreiro-Filho, R. B. Queiroz-Voltan, and S. C. Matthiesen. 2004. Caracterização anatômica de folhas de cafeeiros resistentes e suscetíveis ao bicho-mineiro. Bragantia. 63: 363-372.

Reis, P., and J. Souza. 1986. Pragas do Cafeeiro. In Rena AB et al (eds) Cultura do Cafeeiro - Fatores que afetam a produtividade. Potafós, Piracicaba.

Reis, P., and J. Souza. 1996. Manejo integrado do bicho-mineiro, Perileucoptera coffeella (Guérin-Meneville) (Lepidoptera: Lyonetiidae), e seu reflexo na producao de café. 'Integrated management of the leaf miner, Perileucoptera coffeella (Guérin-Meneville) (Lepidoptera: Lyonetiidae).' An Soc Entomol Bras. 25: 77-82.

Schmitt, J. J., M. W. Brown, and D. R. Davis. 1996. Taxonomy, Morphology, and Biology of Lyonetia prunifoliella (Lepidoptera: Lyonetiidae), a Leafminer of Apple. Ann Entomol Soc Am. 89: 334-345.

Seven, S. 2006. Lyonetiidae of Turkey with notes on their distribution and zoogeography (Lepidoptera). Zootaxa. 1245: 53-58. 
Solis, M. A., and M. A. Metz. 2016. An illustrated guide to the identification of the known species of Diatraea Guilding (Lepidoptera, Crambidae, Crambinae) based on genitalia. Zookeys. 73-121.

Tuelher, E. de S., E. E. de Oliveira, R. N. C. Guedes, and L. C. Magalhães. 2003. Ocorrência de bicho-mineiro do cafeeiro $(<\mathrm{em}>$ Leucoptera coffeella $</$ em $>)$ influenciada pelo período estacional e pela altitude - DOI: 10.4025/actasciagron.v25i1.2458. Acta Scientiarum. Agronomy. 25: 119-124.

Vieira, L. G. E., A. C. Andrade, C. A. Colombo, A. H. de A. Moraes, Â. Metha, A. C. de Oliveira, C. A. Labate, C. L. Marino, C. de B. Monteiro-Vitorello, D. de C. Monte, É. Giglioti, E. T. Kimura, E. Romano, E. E. Kuramae, E. G. M. Lemos, E. R. P. de Almeida, É. C. Jorge, É. V. S. Albuquerque, F. R. da Silva, F. Vinecky, H. E. Sawazaki, H. F. A. Dorry, H. Carrer, I. N. Abreu, J. A. N. Batista, J. B. Teixeira, J. P. Kitajima, K. G. Xavier, L. M. de Lima, L. E. A. de Camargo, L. F. P. Pereira, L. L. Coutinho, M. V. F. Lemos, M. R. Romano, M. A. Machado, M. M. do C. Costa, M. F. G. de Sá, M. H. S. Goldman, M. I. T. Ferro, M. L. P. Tinoco, M. C. Oliveira, M.-A. Van Sluys, M. M. Shimizu, M. P. Maluf, M. T. S. da Eira, O. Guerreiro Filho, P. Arruda, P. Mazzafera, P. D. S. C. Mariani, R. L. B. C. de Oliveira, R. Harakava, S. F. Balbao, S. M. Tsai, S. M. Z. di Mauro, S. N. Santos, W. J. Siqueira, G. G. L. Costa, E. F. Formighieri, M. F. Carazzolle, and G. A. G. Pereira. 2006. Brazilian coffee genome project: an EST-based genomic resource. Brazilian J Plant Physiol. 18: 95-108.

Wheatley, P. E., and T. J. Crowe. 1964. Field studies of insecticides against the coffee leaf-miner Leucoptera meyricki Ghesq. (Lepidoptera, Lyonetiidae). Bull Entomol Res. 55: 193-203.

Wolcott, G. 1947. A quintessence of sensitivity: the coffee leaf-miner. J Agric Univ PR. 31: 215-219. 